\title{
PET studies of the presynaptic and postsynaptic dopaminergic system in Tourette's syndrome
}

\author{
N Turjanski, G V Sawle, E D Playford, R Weeks, A A Lammerstma, A J Lees, D J Brooks
}

\begin{abstract}
Dysfunction of the dopaminergic pathway has been postulated to underlie the symptomatology of Tourette's syndrome. Presynaptic functional integrity of dopaminergic terminals was assessed with ${ }^{18}$ F-dopa PET in 10 patients with Tourette's syndrome, three of whom were drug free and seven of whom were on neuroleptic treatment. Dopamine $D_{2}$ receptor site density was measured with ${ }^{11} \mathrm{C}$-raclopride PET in a further group of five drug free patients with Tourette's syndrome. Mean caudate and putamen ${ }^{18} \mathrm{~F}$-dopa influx constants were similar in patients with Tourette's syndrome and controls, and there was no difference in striatal ${ }^{18} \mathrm{~F}$-dopa uptake between the treated and untreated Tourette's syndrome groups. Mean caudate and putamen ${ }^{11} \mathrm{C}$-raclopride binding potentials in patients with Tourette's syndrome were also similar to control values. The findings suggest that striatal metabolism of exogenous levodopa and the density of striatal $\mathrm{D}_{2}$ receptors are both normal in patients with Tourette's syndrome and that Tourette's syndrome does not arise from a primary dysfunction of dopaminergic terminals.
\end{abstract}

$(F$ Neurol Neurosurg Psychiatry 1994;57:688-692)

Gilles de la Tourette's syndrome is a common disorder, extremely socially disabling in its severest forms. Despite this, little is known about its pathology. It is characterised by simple and complex motor and vocal tics and associated behavioural manifestations such as depression and obsessive-compulsive disorders. ${ }^{1}$ It is possible that obsessive behaviour or multiple tics in isolation may represent an incomplete form of this condition. ${ }^{23}$

Earlier hypotheses that Tourette's syndrome had a psychiatric origin ${ }^{34}$ have now been replaced by the suggestion that it results from a biochemical disturbance, possibly involving the basal ganglia. There is circumstantial evidence implicating several neurotransmitters in the pathogenesis of this syndrome, including the dopaminergic, noradrenergic, serotonergic, cholinergic, GABAergic, and opiod systems..$^{2-4}$ In particular, dysfunction of the dopaminergic pathway has been postulated to play a central part in the pathogenesis of Tourette's syndrome. This dopamine hypothesis is based on the fol- lowing clinical observations: (1) tics usually respond to dopamine receptor antagonists (neuroleptics) and dopamine depleting agents (reserpine, tetrabenazine). (2) Exacerbations of tics have been reported in patients with Tourette's syndrome exposed to dopamine reuptake inhibitors such as cocaine, ${ }^{56}$ and to amphetamines. ${ }^{7}$ (3) Neuroleptic withdrawal can lead to tics. ${ }^{8}$

There is also pathological evidence supporting dysfunction of dopaminergic transmission in Tourette's syndrome. Baseline concentrations of dopamine metabolites have been reported to be reduced in the CSF of patients with Tourette's syndrome. ${ }^{910}$ Postmortem studies with $\left[{ }^{3} \mathrm{H}\right]$ mazindol ${ }^{11}$ found increased dopamine re-uptake site density in striatum from patients with Tourette's syndrome.

To help clarify whether dopaminergic dysfunction underlies Tourette's syndrome, we have assessed the functional integrity of the presynaptic and postsynaptic dopaminergic system with the PET tracers ${ }^{18} \mathrm{~F}$-dopa and ${ }^{11} \mathrm{C}$-raclopride. The striatal uptake and storage of ${ }^{18} \mathrm{~F}$-dopa reflects the activity of aromatic amino acid decarboxylase and subsequent accumulation in the vesicles located in the presynaptic dopaminergic terminals, whereas ${ }^{11} \mathrm{C}$-raclopride is a selective reversible $D_{2}$ receptor antagonist and its uptake reflects $\mathrm{D}_{2}$ site binding potential. ${ }^{12}$

\section{Patients and methods}

PATIENTS

Fifteen patients with Tourette's syndrome were recruited for this study from the movement disorder clinics at the National Hospital of Neurology and Neurosurgery, Queen Square and Charing Cross Hospital, London. Fourteen patients with Tourette's syndrome satisfied DSM-III-R criteria for Tourette's syndrome ${ }^{1}$ and the other had multiple tic disease. Eight had not been given neuroleptic drugs, or had been off medication at least three months before PET. Preliminary data for six of these patients have been previously reported. ${ }^{13}$

\section{Patients studied with ${ }^{18} \mathrm{~F}$-dopa PET}

Ten patients were studied with ${ }^{18} \mathrm{~F}$-dopa PET. Their mean age at the time of PET was 30 (range 18-48) years, and at disease onset it was $6(2-13)$ years. Seven patients (five men, two women), were taking neuroleptic drugs at the time of PET. Three male patients had not been treated with drugs; two had Tourette's 
Table 1 Details of patients with Tourette's syndrome studied with ${ }^{18} \mathrm{~F}$-dopa PET

\begin{tabular}{|c|c|c|c|c|c|c|c|c|c|}
\hline \multirow[b]{2}{*}{ Patient } & \multirow[b]{2}{*}{ Sex } & \multirow{2}{*}{$\begin{array}{l}\text { Age } \\
(y)\end{array}$} & \multirow{2}{*}{$\begin{array}{l}\text { Onset } \\
(y)\end{array}$} & \multicolumn{2}{|l|}{ Simple tics } & \multicolumn{2}{|l|}{ Complex tics } & \multirow{2}{*}{$\begin{array}{l}\text { Obsessions/ } \\
\text { compulsions }\end{array}$} & \multirow[b]{2}{*}{ Current drugs } \\
\hline & & & & Motor & Vocal & Motor & Vocal & & \\
\hline 1 & $\mathbf{M}$ & 48 & 4 & Generalised & $\begin{array}{l}\text { Throat clearing, } \\
\text { barking, shouting }\end{array}$ & Jumping & $\begin{array}{l}\text { Coprolalia, } \\
\text { Echolalia }\end{array}$ & Checking & Chlorprothixene \\
\hline 2 & $\mathbf{F}$ & 24 & 9 & Generalised & $\begin{array}{l}\text { Sniffing, grunting, } \\
\text { barking, shouting }\end{array}$ & $\begin{array}{l}\text { Self injury, } \\
\text { stamping }\end{array}$ & Echolalia & $\begin{array}{l}\text { Complex rituals, } \\
\text { checking }\end{array}$ & Sulpiride \\
\hline 3 & $\mathbf{F}$ & 19 & 3 & Generalised & $\begin{array}{l}\text { Sniffing, barking, } \\
\text { throat clearing }\end{array}$ & Bending legs & None & $\begin{array}{l}\text { Checking rituals, } \\
\text { counting rituals }\end{array}$ & Sulpiride \\
\hline 4 & $\mathbf{M}$ & 18 & 13 & Generalised & $\begin{array}{l}\text { Throat clearing, } \\
\text { clicking }\end{array}$ & $\begin{array}{l}\text { Facial gestures, } \\
\text { touching self }\end{array}$ & None & Checking & Sulpiride \\
\hline 5 & $\mathbf{M}$ & 29 & 2 & Generalised & Sniffing, grunting & $\begin{array}{l}\text { Turning, } \\
\text { touching self }\end{array}$ & Palilalia & $\begin{array}{l}\text { Rituals, } \\
\text { breaking windows }\end{array}$ & Sulpiride \\
\hline 6 & $\mathbf{M}$ & 29 & 5 & Head & Barking, grunting & $\begin{array}{l}\text { Jumping, } \\
\text { knee bends }\end{array}$ & $\begin{array}{l}\text { Echolalia, } \\
\text { coprolalia }\end{array}$ & Counting rituals & $\begin{array}{l}\text { Pimozide, paroxetine, } \\
\text { clonidine, procyclidine }\end{array}$ \\
\hline 7 & $\mathbf{M}$ & 46 & 7 & Head & Shouting & Stamping & Coprolalia & $\begin{array}{l}\text { Breaking objects, } \\
\text { hoarding objects }\end{array}$ & Chlorpromazine \\
\hline 8 & $\mathbf{M}$ & 24 & 7 & Generalised & $\begin{array}{l}\text { Screaming, barking, } \\
\text { grunting }\end{array}$ & $\begin{array}{l}\text { Turning, } \\
\text { self injury }\end{array}$ & Coprolalia & $\begin{array}{l}\text { Breaking objects, } \\
\text { checking }\end{array}$ & None \\
\hline 9 & $\mathbf{M}$ & 26 & 5 & Head & Coughing, sniffing & None & $\begin{array}{l}\text { Echolalia, } \\
\text { coprolalia }\end{array}$ & Counting rituals & None \\
\hline 10 & $\mathbf{M}$ & 44 & 10 & Head & None & None & None & None & None \\
\hline
\end{tabular}

syndrome and one had multiple tic disease. Table 1 summarises patient details and neuroleptic drugs.

The patients' data were compared with a group of 34 control subjects, mean age 58 (range 20-77), and with a subgroup of seven age matched controls, mean age 30 (range 20-55) years.

\section{Patients studied with ${ }^{11} \mathrm{C}$-raclopride PET}

Five men with Tourette's syndrome were studied with ${ }^{11} \mathrm{C}$-raclopride; three had not received drugs, two ceased neuroleptic treatment at least three months before PET, one of them had not received neuroleptics for at least three years before this study. Their mean age when studied was 33 (range 18-46) years, and disease onset occurred at a mean age of 8 (range 5-12) years. One of these patients was also studied with ${ }^{18} \mathrm{~F}$-dopa PET. Table 2 gives the patients' details.

The findings were compared with those of nine control subjects, mean age 50 (range 24-74) years. The data from patients with Tourette's syndrome were also compared with a subgroup of five age matched controls, mean age 36 (range 24-57) years.

The ethics committee of the Royal Postgraduate Medical School, Hammersmith Hospital, approved this study. Permission to give ${ }^{18} \mathrm{~F}$-dopa and ${ }^{11} \mathrm{C}$-raclopride was obtained from the Administration of Radioactive Substances Advisory Committee of the UK. All subjects gave written informed consent.

\section{METHODS}

PET procedure

The PET was performed on a CTI 931/$08 / 12$ scanner at the MRC Cyclotron Unit, Hammersmith Hospital, London, UK. The reconstructed spatial resolution of this scanner, for 15 simultaneously acquired slices, is $7 \cdot 0 \times 8.5 \times 8.5 \mathrm{~mm}$ (full width half maximum). ${ }^{14}$

A thermoplastic head mould was made for each subject to gently immobilise the head while in the scanner. Patients were aligned with the orbitomeatal line parallel to the detector rings. A 10 minute transmission scan was collected with an external ${ }^{68} \mathrm{Ga} /{ }^{68} \mathrm{Ge}$ retractable ring source to correct for tissue attenuation of emitted radiation.

All medication was withdrawn for at least 12 hours before the PET. On the morning of the study, patients ate a light breakfast. One hour before ${ }^{18} \mathrm{~F}$-dopa PET, they received an oral dose of $100 \mathrm{mg}$ carbidopa, a peripheral dopa decarboxylase blocker.

${ }^{18} \mathrm{~F}$-dopa-A mean dose of 123 (SD 41) $\mathrm{MBq}$ of ${ }^{18} \mathrm{~F}$-dopa in $5 \mathrm{ml}$ of normal saline (mean specific activity $6.0 \mathrm{MBq} / \mu \mathrm{mol}$ ) was given by intravenous infusion over two minutes. Scanning began at the start of tracer infusion with collection of 25 serial time frames, increasing in duration from one to five minutes over a study period of 94 minutes.

${ }^{11} \mathrm{C}$-raclopride-A mean dose of 329(SD 61)

Table 2 Details of patients with Tourette's syndrome studied with "C-raclopride PET

\begin{tabular}{|c|c|c|c|c|c|c|c|c|c|}
\hline \multirow[b]{2}{*}{ Patient } & \multirow[b]{2}{*}{ Sex } & \multirow{2}{*}{$\begin{array}{l}\text { Age } \\
(y)\end{array}$} & \multirow{2}{*}{$\begin{array}{l}\text { Onset } \\
(y)\end{array}$} & \multicolumn{2}{|l|}{ Simple tics } & \multicolumn{2}{|l|}{ Complex tics } & \multirow{2}{*}{$\begin{array}{l}\text { Obsessions/ } \\
\text { compulsions }\end{array}$} & \multirow[b]{2}{*}{ Drugs* } \\
\hline & & & & Motor & Vocal & Motor & Vocal & & \\
\hline $1 \dagger$ & $\mathbf{M}$ & 26 & 5 & Head & Coughing, sniffing & None & $\begin{array}{l}\text { Coprolalia, } \\
\text { echolalia }\end{array}$ & Counting rituals & None \\
\hline 2 & $\mathbf{M}$ & 46 & 10 & Face & $\begin{array}{l}\text { Sniffing, grunting, } \\
\text { coughing }\end{array}$ & Touching self & Coprolalia & $\begin{array}{l}\text { Complex rituals, } \\
\text { checking }\end{array}$ & None \\
\hline $\begin{array}{l}3 \\
4\end{array}$ & $\begin{array}{l}M \\
M\end{array}$ & $\begin{array}{l}18 \\
37\end{array}$ & $\begin{array}{l}8 \\
5\end{array}$ & $\begin{array}{l}\text { Head } \\
\text { Generalised }\end{array}$ & $\begin{array}{l}\text { Sniffing, whistling } \\
\text { Throat clearing, } \\
\text { grunting, barking }\end{array}$ & $\begin{array}{l}\text { None } \\
\text { None }\end{array}$ & $\begin{array}{l}\text { None } \\
\text { None }\end{array}$ & $\begin{array}{l}\text { None } \\
\text { None }\end{array}$ & $\begin{array}{l}\text { None } \\
\text { None }\end{array}$ \\
\hline 5 & $\mathbf{M}$ & 39 & 12 & Generalised & Coughing, grunting, & None & None & None & None \\
\hline
\end{tabular}

*At the time of the scan.

†Patient previously studied with ${ }^{18} \mathrm{~F}$-dopa PET (number 9). 
$\mathrm{MBq}$ of tracer in $5 \mathrm{ml}$ of normal saline (mean specific activity: $19072 \mathrm{MBq} / \mu \mathrm{mol}$ ) was injected as a bolus. Scanning began after a 30 second background frame, with collection of 22 serial time frames, increasing from five seconds to 10 minutes duration over a 60 minute study period.

\section{DATA ANALYSIS}

Image analysis was performed with Analyze software (version 5.0.1, BRU, Mayo Foundation, Rochester, MN, USA), on SUN Sparc2 computer workstations. Regions of interest were defined by inspection of an image of integrated tracer activity. This image contained the activity collected from 30-94 minutes for ${ }^{18} \mathrm{~F}$-dopa scans and from $20-60$ minutes for ${ }^{11} \mathrm{C}$-raclopride scans. Regions of interest were placed with a standard template arrangement as previously reported. ${ }^{15}$ Regional time activity plots were then obtained for each region by projecting these regions of interest on the dynamic time frames.

${ }^{18} \mathrm{~F}$-dopa-The data were analysed with a modified multiple time graphical analysis approach, with the occipital lobe as a nonspecific tissue reference input function. ${ }^{15}$ This method generates influx constants ( $K_{\mathrm{i}}$ values), for both caudate and putamen. The $\mathrm{K}_{\mathrm{i}}$ value is an influx constant that reflects the uptake and subsequent metabolism of ${ }^{18} \mathrm{~F}$-dopa by the nigrostrial terminals, and therefore reflects the functional integrity of the dopaminergic projections.

${ }^{11} \mathrm{C}$-raclopride-Regional time activity curves were analysed with a reference tissue model with cerebellar input as described elsewhere. ${ }^{16}$ This method provides estimates of the binding potential of caudate and putamen, a measure of the number of available $\mathrm{D}_{2}$ receptors. ${ }^{12}$

Mean striatal ${ }^{18} \mathrm{~F}$-dopa $\mathrm{K}_{\mathrm{i}}$ values and ${ }^{11} \mathrm{C}$ raclopride binding potentials for each group were compared by Student's unpaired $t$ statistics, with a Bonferroni correction for multiple comparisons $(n=10)$.

\section{Results}

Some patients exhibited tics during PET, but this did not lead to any significant degradation of the images.

\section{${ }^{18} \mathrm{~F}$-dopa PET}

The mean values for caudate and putamen ${ }^{18} \mathrm{~F}$-dopa influx constants were similar in patients with Tourette's syndrome and controls. All individual patient caudate and putamen $K_{i}$ values were within two SDs of the normal mean (fig 1). The Tourette's syndrome $K_{i}$ values were also similar to the subgroup of age matched normal controls (mean normal caudate: $0.0098(0.0011)$, putamen: $\left.0.0093(0.0009) \mathrm{min}^{-1}\right)$. There were no differences in striatal ${ }^{18} \mathrm{~F}$-dopa $K_{i}$ values between treated and untreated Tourette's syndrome.

${ }^{11} \mathrm{C}$-raclopride PET

The mean caudate and putamen binding

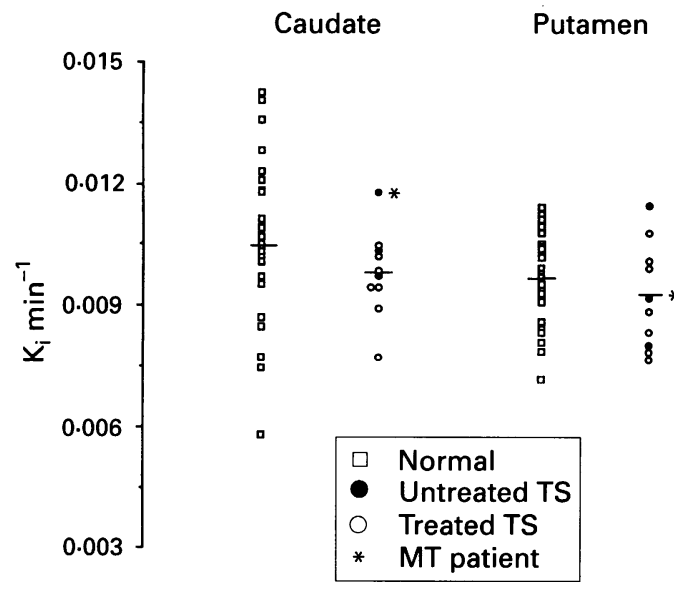

Figure 1 Scatter diagram showing individual caudate and putamen ${ }^{18} \mathrm{~F}$-dopa influx constants for patients with Tourette's syndrome (TS) and controls. All patients $K_{i}$ values were within two SDs of the control mean. No significant difference was found between mean striatal $K_{\text {. }}$ values for treated and untreated Tourette's syndrome groups; $M T=$ multiple tic disease.

potentials in Tourette's syndrome were similar to control values. Figure 2 shows individual caudate and putamen binding potentials for Tourette's syndrome and control subjects. All except one lay within two SDs of the normal means. When the patients with Tourette's syndrome were compared with a smaller subgroup of five age matched normal controls, mean binding potentials of both groups remained similar (mean normal caudate: $2 \cdot 36(0 \cdot 19)$ and putamen: $2 \cdot 45(0 \cdot 07))$.

\section{Discussion}

Our nine patients with Tourette's syndrome and one patient with multiple tic disease studied with ${ }^{18}$ F-dopa PET all had normal uptake and storage of this tracer in their nigrostriatal dopaminergic terminals. A further group of five patients with Tourette's syndrome studied with ${ }^{11} \mathrm{C}$-raclopride exhibited normal postsynaptic striatal $\mathrm{D}_{2}$ receptor binding potentials.

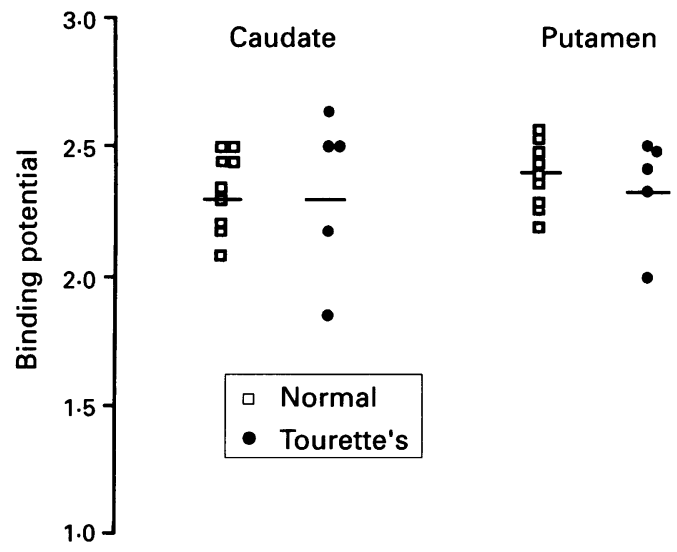

Figure 2 Scatter diagram showing individual caudate and putamen ${ }^{11} \mathrm{C}$-raclopride binding potentials for patients with Tourette's syndrome and controls. Binding potential values for four out of five patients were within two SDs of the normal mean. 
As seven of the 10 patients scanned with ${ }^{18} \mathrm{~F}$-dopa were receiving chronic neuroleptic treatment at the time of PET it is necessary to consider the effects of these drugs on the activity of aromatic amino acid decarboxylase, the enzyme in the dopaminergic terminals responsible for decarboxylating exogenous ${ }^{18} \mathrm{~F}$-dopa. The effects of acute neuroleptic treatment on the dopaminergic presynaptic projections are well established; however, the effects of chronic treatment are still uncertain. Studies on rats have shown increased release of striatal dopamine, and increased aromatic amino acid decarboxylase activity, after acute challenges with dopamine $D_{1}$ and $D_{2}$ antagonists. ${ }^{17} 18$ Chronic haloperidol treatment decreased basal dopamine release, ${ }^{19}$ although we have been unable to find data about its effect on aromatic amino acid decarboxylase activity. Our own preliminary experiments suggest that such activity may become mildly raised in the rat striatum (Opacka-Juffry, personal communication). This could lead to a slight increase in striatal ${ }^{18} \mathrm{~F}$-dopa uptake, although none was evident in our Tourette's syndrome group.

Decreased concentrations of the dopamine metabolite homovanillic acid and the serotonin metabolite 5-hydroxyindoleacetic acid have been reported in the CSF of patients with Tourette's syndrome. ${ }^{910}$ Postmortem studies with $\left[{ }^{3} \mathrm{H}\right]$ mazindol, have suggested increased dopaminergic reuptake site density ( $37 \%$ in caudate and $50 \%$ in putamen) in patients with Tourette's syndrome. Concentrations of dopamine and its metabolites in the striatum were, however, normal. ${ }^{11}$ The striatal concentration of adenosine 3',5'monophosphate (cyclic AMP) has also been reported to be reduced in four patients with Tourette's syndrome. ${ }^{20}$ In the light of these findings, it has been postulated that the primary defect in Tourette's syndrome could be abnormal dopamine turnover within the striatum, or abnormal second messenger production. ${ }^{1120}$ In our ${ }^{18} \mathrm{~F}$-dopa PET study all patients with Tourette's syndrome had caudate and putamen influx constants within two SDs of the normal mean. Consequently, our PET findings do not support the presence of a primary dysfunction of dopa metabolism in the presynaptic dopaminergic terminals.

Rituals and obsessive behaviour were a clinical feature in nine of our 10 patients studied with ${ }^{18} \mathrm{~F}$-dopa. Our results are in agreement with a previous ${ }^{18} \mathrm{~F}$-dopa study that reported normal striatal tracer uptake in patients with obsessional slowness. ${ }^{21}$

Singer and coworkers found normal striatal $D_{1}$ and $D_{2}$ receptor density ${ }^{11}$ in Tourette's syndrome postmortem studies. Wong and colleagues, in a preliminary ${ }^{11} \mathrm{C}$-methylspiperone PET study, detected increased $\mathrm{D}_{2}$ receptor density in four patients with Tourette's syndrome. ${ }^{22}$ More recently, the same group reported caudate/cerebellar ratios in 19 patients with Tourette's syndrome and found no overall mean difference when the results were compared with controls, although there was increased variance in patient values. ${ }^{23}$ Our findings of normal striatal $\mathrm{D}_{2}$ site binding in four out of five patients with Tourette's syndrome studied with ${ }^{11} \mathrm{C}$-raclopride are in accordance with the above report.

Metabolic PET studies in patients with Tourette's syndrome under resting condition have shown hypermetabolism in selective areas of the brain. A preliminary ${ }^{18} \mathrm{~F}$-2-fluoro2-deoxyglucose $\left({ }^{18} \mathrm{FDG}\right)$ PET study in drug free patients with Tourette's syndrome found a $16 \%$ increase in glucose utilisation in the basal ganglia of patients with Tourette's syndrome compared with controls and relative hypermetabolism in frontal and temporal areas bilaterally. ${ }^{24}$ Later, the same group reported regional hypermetabolism in superior frontal and sensorimotor cortices and suggested that the normal relation between the function of motor cortex and other brain regions was disturbed. ${ }^{25} \mathrm{~A}$ confounding problem, however, is that these patients may have had tics during the ${ }^{18} \mathrm{FDG}$ PET. It remains unclear, therefore, how much of the increased activity represented tic generation, and how much simply reflected increased motor activity. Sawle et $a l^{26}$ recently reported a PET study of regional cerebral oxygen metabolism before and after cingulotomy in a patient with Tourette's syndrome. Interestingly, preoperatively there was caudate and thalamus hypermetabolism, but after cingulotomy the metabolic rate decreased considerably in the caudate, in association with improvement of both tics and obsessive-compulsive syndrome.

In conclusion, using ${ }^{18} \mathrm{~F}$-dopa and ${ }^{11} \mathrm{C}$ raclopride PET, we have been unable to find any abnormality of dopamine metabolism and storage in the nigrostriatal dopaminergic terminals, or in the density of striatal postsynaptic $\mathrm{D}_{2}$ receptors in patients with Tourette's syndrome. Our findings, however, do not exclude a dysfunction of endogenous dopamine production, or altered proportions of $\mathrm{D}_{2}$ receptors in high and low agonist affinity conformations ${ }^{7}$ in this condition.

We thank colleagues of the Chemistry and PET methods sections at the MRC Cyclotron Unit for their expert assistance and also Mrs A Williams, Ms CJV Taylor, and Mr GC Lewington for their help with scanning.

1 American Psychiatric Association. Diagnostic and statistical manual of mental disorders. 3rd ed. revised. Washington DC: American Psychiatric Press, 1987.

2 Kurlan R. Tourette's syndrome: Current concepts. Neurology 1989;39:1625-30.

3 Singer HS, Walkup JT. Tourette syndrome and other tic disorders. Diagnosis, pathophysiology, and treatment. Medicine 1991;70:15-31.

4 Dugas $M$. Le syndrome de Gilles de la Tourette. Etat actuel de la maladie des tics. Presse Med 1985;14: 589-93.

5 Factor SA, Sanchez-Ramos JR, Weiner W. Cocaine and Tourette's syndrome. Ann Neurol 1988;4:423-4.

6 Mesulam MM. Cocaine and Tourette's syndrome. $N$ Engl F Med 1986;315:398.

7 Pollack MA, Cohen NL, Friedhoff AJ. Gilles de la Tourette's syndrome. Familial occurrence and precipitation by methylphenidate therapy. Arch Neurol 1977;34: 630-2.

8 Klawans HL, Falk DK, Nausieda PA, Weiner WJ. Gilles de la Tourette syndrome after long-term chlorpromazine therapy. Neurology 1978;28:1064-8.

9 Butler IJ, Koslow SH, Seifert WE, Caprioli RM, Singer HS. Biogenic amine metabolism in Tourette syndrome. Ann Neurol 1979;6:37-9.

10 Goetz CG, Tanner CM. Gilles de la Tourette's syndrome 
in twins: clinical and neurochemical data. Mov Disord 1990;5:173-5

11 Singer HS, Hahn IH, Moran TH. Abnormal dopamine uptake sites in postmortem striatum from patients with Tourette's syndrome. Ann Neurol 1991;30:558-62.

12 Farde L, Hall H, Ehrin E, Sedvall G. Quantitative analysis of $\mathrm{D}_{2}$ receptor binding in the living human brain by PET Science 1986:231:258-61.

13 Brooks DJ, Turjanski N, Sawle GV, Playford ED, Lees AJ. PET studies on the integrity of the pre- and post-synaptic dopaminergic system in Tourette's syndrome. $A d v$ Neurol 1992;58:227-33.

14 Spinks TJ, Jones T, Gilardi MC, Heather JD. Physical performance of the latest generation of commercial positron scanner. IEEE Trans Nucl Sci 1988;35:721-5.

15 Brooks DJ, Salmon EP, Mathias CJ, et al. The relationship between locomotor disability, autonomic dysfunction, and the integrity of the striatal dopaminergic system, in patients with multiple system atrophy, pure autonomic patients with multiple system atrophy, pure autonomic 1990;113:1539-52.

16 Hume SP, Myers R, Bloomfield PM, et al. Quantitation of carbon-11 labelled raclopride in rat striatum using carbon-11 labelled raclopride in rat striatum using

17 Zhu MY, Juorio AV, Paterson IA, Boulton AA. Regulation of aromatic L-aminoacid decarboxylase by dopamine receptors in the rat brain. $\mathcal{F}$ Neurochem 1992;58:636-41.

18 See RE, Sorg BA, Chapman MA, Kalivas PW. In vivo assessment of release and metabolism of dopamine in the ventrolateral striatum of awake rats following administration of dopamine D1 and D2 receptor agonists and antagonists. Neuropharmacology 1991;30:1269-74.
19 Lane RF, Blaha CD, Rivet JM. Selective inhibition of mesolimbic dopamine release following chronic administeson of dopamine tration of clozapine: involvement of $a_{1}$-noradrenergic receptors demonstrated by in vivo voltammetry. Brain
Res 1988;460:398-401.

20 Singer HS, Hahn IH, Krowiak E, Nelson E, Moran T. Tourette's syndrome: a neurochemical analysis of postmortem cortical brain tissue. Ann Neurol 1990;27:443-6.

21 Sawle GV, Hymas NF, Lees AJ, Frackowiak RSJ. Obsessional slowness. Functional studies with positron emission tomography. Brain 1991;114:2191-202.

22 Wong DF, Pearlson GD, Young LT, et al. D2 dopamine receptors are elevated in neuropsychiatric disorders other than schizophrenia. $\mathcal{f}$ Cereb Blood Flow Metab 1989;9(suppl 1):S593.

23 Singer HS, Wong DF, Brown JE, et al. Positron emission tomography evaluation of dopamine D-2 receptors in adults with Tourette syndrome. Adv Neurol 1992;58: 233-9.

24 Chase TN, Foster NL, Fedio P, et al. Gilles de la Tourette syndrome: studies with the Fluorine-18-labelled Fluorodeoxiglucose positron emission tomography. Ann Feurol 1984;15:S175.

25 Stoetter B, Braun AR, Randolph C, et al. Functional neuroanatomy of Tourette syndrome. Limbic-motor interroanatomy of Tourette syndrome. Limbic-motor inter213-26.

26 Sawle GV, Lees AJ, Hymas NF, Brooks DJ, Frackowiak RSJ. The mechanisms of clinical improvement in Gilles de la Tourette syndrome following limbic leucotomy: PET demonstrates changes in regional cerebral oxygen metabolism (abstract). Mov Disord 1992;7(suppl 1):51.

\section{NEUROLOGICAL STAMP}

\section{François Magendie (1783-1855)}

François Magendie, born in Bordeaux in 1783, was appointed Professor of Medicine at the College de France in Paris in 1831. He made important discoveries in neurophysiology and nutrition and is regarded by some as the father of experimental pharmacology. $\mathrm{He}$ is best remembered for his work on the cerebrospinal fluid and the canal in the brain that bears his name. One of his most important contributions was proof (in a litter of puppies) that the anterior roots of the spinal nerve were motor and the posterior sensory. A bitter dispute over the priority for the discovery ensued with the distinguished physiologist Charles Bell.

Magendie was also the first to produce decerebrate rigidity, the effects of excision or section of the cerebellum and of "circus movement" resulting from a lesion of the optic thalamus.

His investigations in pharmacology introduced bromine, quinine, emetine, and morphine into medical practice and he showed the effect of strychnine on the paralysed spinal cord. His Formulaire was published in 1821.

In 1815, post-revolutionary France was short of food. Magendie was appointed Chairman of a Commission to investigate the nutritional value of various food extracts. He showed the need for adequate amounts of the right sort of protein in a diet, laying the foundations for the science of nutrition. In 1842 he published an influential book that helped to reform clinical medicine along physiological lines.

He died on his birthday in 1855 and was honoured in 1985 in the Heroes of Medicine series issued by the Republic of Transkei. (Stanley Gibbons 178).

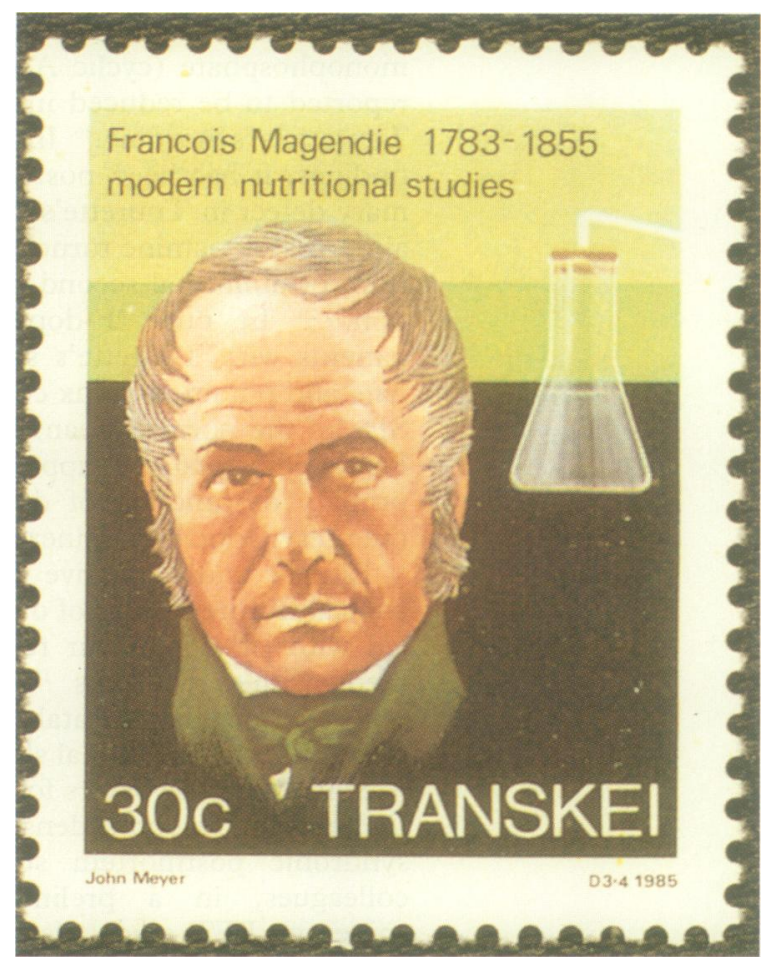

